\title{
Comparative Prospects of the New Development Bank and Asian Infrastructure Investment Bank ${ }^{1}$
}

\section{A. Shelepov}

\begin{abstract}
Andrey Shelepov - Researcher, Center for International Institutions Research, Russian Presidential Academy of National Economy and Public Administration; 11 Prechistenskaya Naberezhnaya, 119034 Moscow, Russian Federation; E-mail: shelepov-av@ranepa.ru

In this article, the author focuses on the recently-established New Development Bank (NDB) and Asian Infrastructure Investment Bank (AIIB). It identifies two factors which have created the demand for this new model of multilateral development banks (MDBs), namely, a lack of infrastructure financing and the aspirations of developing countries for a greater role in the global financial system. The author also compares the NDB and AIIB in terms of membership, management structure, distribution of capital and votes, and options for attracting capital in financial markets. Based on this comparison, he forecasts the banks' credit portfolios' growth until 2025. The author concludes that both institutions should accumulate and use the best practices of existing MDBs, improve their image to attract investors, and actively engage in sharing expertise and co-financing projects with development institutions as well as commercial banks. By doing so, the volume of their operations could reach $\$ 40$ billion per year in 10 years, which is close to the volume of infrastructure financing provided by major traditional banks, and could contribute substantially to addressing the financing needs of developing countries.
\end{abstract}

Key words: New Development Bank, Asian Infrastructure Investment Bank, BRICS, global financial architecture, multilateral development banks, infrastructure investment

\section{Introduction}

On 15 July 2014, at the Fortaleza summit, the BRICS leaders announced the signing of the Agreement on the New Development Bank (NDB). On 24 October 2014, 21 Asian countries signed a Memorandum of Understanding on the establishment of the Asian Infrastructure Investment Bank (AIIB). The almost simultaneous launch of these new multilateral development banks (MDBs) was caused by several reasons, including a significant lack of investment in the maintenance of existing infrastructure, as well as the construction of new infrastructure around the world, particularly in developing countries; concerns about the ability of the existing MDBs to respond effectively to this challenge; disbalances between the positions of the leading developing countries and emerging economies in the global economy and their roles in traditional international financial institutions (Table 1).

${ }^{1}$ The article is published within the framework of a research project "The prospects of the New Development Bank and Asian Infrastructure Investment Bank and their potential role in transforming the global financial architecture" (2016) of the Center for International Institutions Research (CIIR) of the Russian Presidential Academy of National Economy and Public Administration (RANEPA).

The article was submitted to the editors in May 2016. 
Table 1. BRICS countries' percentage of votes in the IBRD and their share in the global GDP

\begin{tabular}{|l|c|c|c|}
\hline \multirow{2}{*}{} & \multirow{2}{*}{$\begin{array}{c}\text { Share of votes in the } \\
\text { IBRD }\end{array}$} & \multicolumn{2}{|c|}{ Share in the global GDP based on PPP, \% } \\
\cline { 3 - 4 } & & 2014 & 2018 (forecast) \\
\hline Brazil & 1.85 & 3.01 & 2.63 \\
\hline Russia & 2.91 & 3.29 & 2.80 \\
\hline India & 3.06 & 6.81 & 7.91 \\
\hline China & 4.65 & 16.63 & 18.48 \\
\hline South Africa & 0.78 & 0.65 & 0.61 \\
\hline Total & $\mathbf{1 3 . 2 5}$ & $\mathbf{3 0 . 3 9}$ & $\mathbf{3 2 . 4 4}$ \\
\hline
\end{tabular}

Source: IBRD subscriptions and voting power of member countries, ${ }^{2}$ IMF WEO Database, October 2015.

At the same time, the basic principles of financing through multilateral development banks are recognized as relatively effective, including by these countries. As a result, new institutions established on their initiative use business models typical of the traditional MDBs. However, some individual parameters of these two new banks differ. Despite the fact that both institutions have been established recently, peculiarities regarding their capital structure, governance and operations allow carrying out the analysis of their comparative prospects and thus assessing their potential effectiveness in addressing relevant objectives.

The relevance of analyzing the comparative prospects of the NDB and AIIB is highlighted by the growing interest of researchers in this subject. For instance, S. Griffith-Jones [GriffithJones, 2014] examines different scenarios of the NDBs' activities aimed at eliminating the global infrastructure investment deficit and comes to a conclusion regarding the genesis of a new type of MDBs [Griffith-Jones, 2015], whereas C. Humphrey carries out the comparative analysis of development outlooks for the two banks [Humphrey, 2015b].

\section{NDB and AllB background}

The main factor facilitating the effectiveness of the project financing model involving multilateral development banks is their ability to maintain a stable volume of lending without any additional contributions by shareholders (apart from the initial paid-in capital). MDBs are also attractive for borrowers because high credit ratings usually allow these banks to raise funds at low cost on capital markets, making their loans more affordable. In addition, along with financial support, MDBs often provide technical assistance, which is also an important factor for borrowers, as most of them are developing countries.

At the same time, given the current conditions, MDBs do not fully cope with their tasks because of two factors. Firstly, the capabilities of MDBs are not sufficient to meet the rapidly growing demand for investments in large-scale infrastructure projects around the world, especially in developing countries, where it is estimated to reach USD $1^{3}-2.3$ trillion annu-

${ }^{2}$ IBRD subscriptions and voting power of member countries. Available at: http://siteresources. worldbank.org/BODINT/Resources/278027-1215524804501/IBRDCountryVotingTable.pdf (accessed 03 August 2016).

${ }^{3}$ BRICS New Development Bank not to compete with other international financial institutions - president. OANA, 11 December 2015. Available at: http://www.oananews.org/content/news/bussiness/brics-newdevelopment-bank-not-compete-other-international-financial (accessed 03 August 2016). 
ally [Bhattacharya, Romani, 2013]. At the same time, according to S. Griffith-Jones, actual investments in recent years totaled about USD 1 trillion, indicating the existence of a substantial financing gap [Griffith-Jones, 2014]. The elimination of this deficit through private sector investments is difficult due to complexities associated with assessing risks and protection from them in developing countries. Moreover, MDBs, which are better able to minimize these risks, have recently reduced the share of infrastructure investment in the total volume of their operations in favor of lending in other areas. As a result, the annual volume of financing made available for infrastructure projects by major MDBs in recent years has not exceeded an average of USD 40 billion [Humphrey, 2015a], while the total amount of their investment reached USD 100 billion. ${ }^{4}$

Secondly, major MDBs were created at a time when the global economic order was based on the dominance of the developed countries of Europe, the United States and Japan (the IBRD was established in 1945, the Asian Development Bank (ADB) in 1966, the African Development Bank (AfDB) in 1963, and the Inter-American Development Bank (IDB) in 1959). This helped these countries keep the leading role in the abovementioned MDBs, actually having control over their decision-making mechanisms. Reforms aimed, inter alia, at addressing imbalances between the growing weight of developing countries and emerging economies in the global economy, and their disproportionately weak positions in the MDBs are implemented very slowly.

For these reasons, emerging economies began coming up with the idea of creating new development financing institutions, taking into account their interests and at the same time using the experience gained by traditional MDBs. The accumulation of large reserves in these countries, especially in China, has become a further impetus for the creation of new institutions. It should be mentioned that these assets are usually placed in sovereign wealth funds and invested mainly in the financial instruments of developed countries with relatively low yields [Griffith-Jones, 2011].

All these reasons led to an active discussion of the idea of establishing new development banks that could contribute to financing the required investment, especially in infrastructure, supplementing the resources of existing MDBs, by major emerging economies, primarily in the framework of BRICS.

At the 2012 New Delhi summit, India launched the dialogue between the BRICS countries on the possibilities of creating their own development bank. The leaders of the five countries discussed setting up a bank "for mobilizing resources for infrastructure and sustainable development projects in the BRICS and other emerging economies and developing countries" [BRICS Leaders, 2012]. They noted that the new bank could supplement the activities of international and regional financial institutions to facilitate global growth and development. At the summit, BRICS leaders instructed their countries' finance ministers to examine the feasibility and viability of such an initiative with the assistance of a special working group and to report on the results by their next meeting.

Following the report submitted to the Durban summit in March 2013, the BRICS leaders "noted with satisfaction" that the creation of this new financial institution is appropriate and viable. They decided that the newly-created institution will be called the New Development Bank, and agreed that its resources should be "substantial and sufficient for the Bank to be effective in financing infrastructure" [BRICS Leaders, 2013a]. By September 2013, considerable progress had been achieved in creating the NDB. At the informal meeting on the eve of G20 summit in

${ }^{4}$ BRICS New Development Bank not to compete with other international financial institutions - president. OANA, 11 December 2015. Available at: http://www.oananews.org/content/news/bussiness/brics-newdevelopment-bank-not-compete-other-international-financial (accessed 03 August 2016). 
St. Petersburg, BRICS leaders announced talks regarding the capital structure, membership, shareholding and governance of the new institution. They also agreed on the Bank's initial subscribed capital of USD 50 billion [BRICS Leaders, 2013b]. Finally, at the Fortaleza summit on 15 July 2014, the leaders announced the signing of the agreement establishing the New Development Bank and announced the main parameters of its capital: initial authorized capital of USD 100 billion and, as planned previously, subscribed capital of USD 50 billion distributed equally between the member states. The BRICS leaders instructed their finance ministers to work out the modalities for NDB operationalization [BRICS Leaders, 2014]. Additionally, at the Fortaleza summit the text of the Agreement on the New Development Bank was published, determining the basic parameters and aspects of its operations. All member countries had ratified the Agreement by the BRICS Ufa summit (July 2015). The Ufa Declaration stated that inaugural projects should be financed by the NDB in the first half of 2016.

As for the AIIB, the initiative to create the lending institution was announced in October 2013 by Chinese President Xi Jinping and Premier of the State Council Li Keqiang. They specified that its main objectives would be to promote interconnectivity and economic integration in the region, primarily on the basis of cooperation with existing MDBs. ${ }^{5}$ Later, representatives of the AIIB stated that the bank "will work with its members, multilateral and bilateral development partners, private sector and civil society" to improve access to basic services, including a reliable power supply, efficient transportation systems, clean water, sanitation and modern telecommunications. Funding through the AIIB was expected to supplement and enhance the effectiveness of MDBs and other partners' activities in these areas, as well as in rural infrastructure and agriculture development, environmental protection, urban development and logistics. $^{6}$

Speaking at the Boao Forum for Asia in April 2014, Li Keqiang announced the launch of consultations with partners in Asia and beyond on the preparations for the establishment of the Asian Infrastructure Investment Bank. ${ }^{7}$ Initially it was assumed that the subscribed capital of the AIIB would amount to USD 50 billion, but in June 2014 a proposal to double the capital was announced. ${ }^{8}$ At the same time, consultations were launched with partners on participation in the AIIB as shareholders. India became one of the first countries invited. ${ }^{9}$

Following the announcement of the AIIB's launch, bilateral and multilateral negotiations and consultations were carried out concerning its basic principles and key areas of activities. On 24 October 2014, 21 Asian countries signed the Memorandum of Understanding on setting up the AIIB (Indonesia signed the MoU with a slight delay due to the change of the presidential administration ${ }^{10}$ ), which contained a decision to locate the bank's headquarters in Beijing. Jin Liqun of China was appointed as the Secretary General of the AIIB Multilateral Interim Secretariat, responsible for technical preparations for the launch of the bank's operations and

${ }^{5}$ History of AIIB. Asian Infrastructure Investment Bank. Available at: http://euweb.aiib.org/html/aboutus/introduction/history/?show $=0$ (accessed 03 August 2016).

${ }^{6}$ What is the AIIB? Asian Infrastructure Investment Bank. Available at: http://euweb.aiib.org/html/ aboutus/introduction/aiib/?show $=0$ (accessed 03 August 2016).

${ }^{7}$ China eyes closer Asia's economic integration through Asian infrastructure bank. GBTIMES Beijing, 11 April 2014. Available at: http://gbtimes.com/china/china-eyes-closer-asias-economic-integration-throughasian-infrastructure-bank (accessed 03 August 2016).

${ }^{8}$ Chinese alternative to the World Bank will et USD 100 billion. RBC, 25 June 2014. Available at: http:// www.rbc.ru/economics/25/06/2014/932610.shtml (accessed 03 August 2016).

${ }^{9}$ China invites India to join Asian Infrastructure Investment Bank. The Hindu, 30 June 2014. Available at: http://www.thehindu.com/todays-paper/tp-national/china-invites-india-to-join-asian-infrastructure-investment-bank/article6161311.ece (accessed 03 August 2016).

${ }^{10}$ Indonesia becomes 22nd founding member of AIIB. Xinhua, 27 November 2014. Available at: http:// news.xinhuanet.com/english/world/2014-11/27/c_133818862.htm (accessed 03 August 2016). 
organizing meetings between the founding members. Five rounds of negotiations between prospective founding members were held, the last of them took place on 22 May 2015 in Singapore; it resulted in the adoption of the final AIIB's Articles of Agreement. On 29 June the Articles of Agreement were signed by 50 countries - prospective founding members (seven more countries had completed the signing procedure by 31 December 2015). At the same time, the process of ratification of the Articles was launched. On 25 December 2015, when the total capital subscription of countries that had ratified the Articles exceeded 50\%, they officially entered into force. ${ }^{11}$ The process of ratification by other signatories continues and is expected to be completed by the end of 2016. ${ }^{12}$

Thus, a significant lack of infrastructure investment around the world and the aspiration of emerging economies to strengthen their influence in international financial institutions have become the main factors driving the establishment of the new development banks. The banks examined in this article were established almost simultaneously. Their operations also started in the same period. Thus, in April 2016 the NDB approved its first loans for projects in four countries, totaling USD 811 million. The AIIB is expected to finance projects worth USD 1.2 billion in 2016. ${ }^{13}$

At the same time, it seems that, despite the similarity of their objectives, the two new MDBs are unlikely to compete with each other, at least at the initial stage of their development. On the contrary, the existence of several institutions with overlapping country priorities (in Asia) provides possibilities for cooperation between them, in particular through syndicated loans for large projects. BRICS leaders supported such cooperation, for example, welcoming in the Ufa Declaration "the proposal for the NDB to cooperate closely with existing and new financing mechanisms including the Asian Infrastructure Investment Bank" [BRICS Leaders, 2015].

At the same time, the possibilities for the NDB and AIIB to become important actors in the system of infrastructure project financing and cooperation between development banks in this area will largely depend on their capital structure and corporate governance mechanisms, opportunities for attracting new members and raising external funding, determined, inter alia, by credit ratings and the interoperability of the two institutions and their success in effective collaboration with "traditional" MDBs. Comparisons of these parameters, as well as AIIB and NDB development forecasts are presented below.

\section{Membership, capital structure and votes}

The amount of share capital of multilateral development banks is an important parameter because it directly affects their ability to raise funds from external sources and, therefore, the scope of banks' operations, thus determining their ability to fulfill stated goals. In addition, distribution of capital is always directly related to the role of members in the governance of MDBs. In this regard, initial decisions on the structure of the MDBs' capital play a significant role in the process of their further development.

The initial authorized capital of the NDB is USD 100 billion. This amount of capital is divided into 1 million shares with a par value of USD 100,000 each, which are available for sub-

${ }^{11}$ Signing and Ratification Status of the AOA of the AIIB. Asian Infrastructure Investment Bank. Available at: http://euweb.aiib.org/html/aboutus/introduction/Membership/?show=0 (accessed 03 August 2016).

${ }^{12}$ History of AIIB. Asian Infrastructure Investment Bank. Available at: http://euweb.aiib.org/html/ aboutus/introduction/history/?show $=0$ (accessed 03 August 2016).

${ }^{13}$ AIIB and World Bank sign first Co-Financing Framework Agreement. Asian Infrastructure Investment Bank. Available at: http://euweb.aiib.org/html/2016/NEWS_0414/99.html (accessed 03 August 2016). 
scription only by members of the Bank. The value of one share, i.e. USD 100,000, is the minimum amount to be subscribed for participation. The initial subscribed capital of the Bank is set at USD 50 billion. The subscribed capital is divided into paid-in shares and callable shares. The aggregate par value of paid-in shares is USD 10 billion. Consequently, shares with a total par value of USD 40 billion are callable. Each member of the NDB is obliged to subscribe to shares of its capital stock. Initially five founding members subscribed to equal shares in the capital of the Bank (USD 50 billion) that amount to 100 thousand shares, or USD 10 billion (this means that these shares were issued at par value), of which 20 thousand are paid-in shares with a total value of USD 2 billion, and 80 thousand shares are callable with a par value of USD 8 billion [BRICS Governments, 2014].

The decision on equal stakes of the founding members in the NDB capital is based on the principle of equality among the BRICS countries and their desire to move away from the practice of traditional MDBs, where members with greater economic weight are usually entitled to higher capital shares (and thus have a greater impact in institutions' governance systems). At the same time, this decision has led to a limitation of the NDB's capital, based on the potential of the smallest economy among the founding members - South Africa. As it was previously noted, large foreign exchange reserves in the BRICS countries were one of the factors favoring the NDB's establishment. However, their size in China is much larger than the figures in India, Brazil and Russia, which, in turn, greatly exceed South African reserves. In early 2016, official reserves reached USD 3.3 trillion in China, 380 billion in Russia, 360 billion in India and Brazil and only slightly exceeded USD 45 billion in South Africa. ${ }^{14}$ Based on these figures, the Contingent Reserve Arrangement worth USD 100 billion, which was created simultaneously with the NDB, provides for the following obligations of its participants: China - USD 41 billion, Brazil, India and Russia - USD 18 billion each, and South Africa - USD 5 billion..$^{15}$ If the same crosscountry proportions are adopted for the NDB capital through greater use of member countries' reserves, its amount could significantly exceed the current figures. It should be also noted that the NDB has chosen the simplest way to link the countries' shares in capital and their voting power: the number of votes of each NDB member equals its number of subscribed shares (i.e. this figure is the same for all of the founding members and currently amounts to 100,000 votes). The NDB's attractiveness for potential member countries could increase if the bank adopted alternative mechanisms. For example, if it used so-called basic votes, distributed equally among all members regardless of their contribution to the capital of the bank (this mechanism is used in the AIIB), the impact of countries' economic potential, which determines shares in capital, on their abilities to influence the bank's decision-making process could be mitigated.

Similarly to the New Development Bank, the authorized capital of the AIIB amounts to USD 100 billion divided into 1 million shares having a par value of USD 100,000. The AIIB uses the same ratio between its paid-in capital and callable capital as the NDB (20 to 80). ${ }^{16}$

Other parameters of capital and votes distribution in the AIIB differ substantially from that of the NDB. The number of shares to which each AIIB member may subscribe is determined by the size of its respective economy in relation to other members on the basis of the weighted

${ }^{14}$ Data Template on International Reserves and Foreign Currency Liquidity. International Monetary Fund. Available at: https://www.imf.org/external/np/sta/ir/IRProcessWeb/colist.aspx (accessed 03 August 2016).

${ }^{15}$ On signature by BRICS central banks of the Operational Agreement in the framework of the Pool of Conventional Currency Reserves. Bank of Russia, 7 July 2015. Available at: http://www.cbr.ru/eng/press/PR.a spx?file=07072015_162908eng2015-07-07T16_11_18.htm (accessed 03 August 2016).

${ }^{16}$ Asian Infrastructure Investment Bank Articles of Agreement. Available at: http://euweb.aiib.org/uplo adfile/2016/0202/20160202043950310.pdf (accessed 03 August 2016). 
index (60\% of nominal GDP and $40 \%$ of GDP based on PPP). ${ }^{17}$ The mechanism of votes distribution in the AIIB is also more complex than in the NDB. The total voting power of each member is the sum of its basic votes, share votes and Founding Member votes (if the member is one of the AIIB 57 founding members). Basic votes are defined as those resulting from the equal distribution among all the members of 12 percent of the total sum of votes. The number of share votes equals to the number of shares of the AIIB capital stock held by a particular member. In addition, each founding member is allocated 600 additional votes. As a result, when all 57 prospective founding members ratify the Articles of Agreement, the vote distribution scheme in the AIIB will look as shown in Table 2. As an illustration, the amounts of votes of China and the Maldives - countries with the largest and smallest number of votes respectively - are presented. The number of votes allocated to Maldives is almost 100 times less than that of China. At the same time, the share of Maldives in the AIIB capital is approximately 3,000 times less than the share of China. Thus, using basic votes and Founding Member votes allows the AIIB, on the one hand, to attract countries with very limited financial resources as shareholders and, on the other hand, to demonstrate respect to such countries by giving to them more voting power compared to less complex vote distribution models.

Table 2. Distribution of voting power in the AIIB

\begin{tabular}{|l|c|c|c|c|c|}
\hline \multicolumn{1}{|c|}{ Type of votes } & \% of total votes & Number of votes & $\begin{array}{c}\text { Number of votes } \\
\text { per member }\end{array}$ & China & The Maldives \\
\hline Basic votes & 12 & 138,510 & 2,430 & 2,430 & 2,430 \\
\hline Share votes & 85 & 981,514 & Variable number & 297804 & 72 \\
\hline $\begin{array}{l}\text { Founding } \\
\text { Member votes }\end{array}$ & 3 & 34,200 & 600 & 600 & 600 \\
\hline Total & 100 & $1,154,224$ & Variable number & $300,834(26.1 \%)$ & $3,102(0.3 \%)$ \\
\hline
\end{tabular}

Source: AIIB Articles of Agreement, ${ }^{18}$ author's calculations.

The AIIB Articles of Agreement suggest that its regional members shall hold at least $75 \%$ of its subscribed capital. Similar "regional" restrictions are also adopted in the AIIB governance structure. For example, in its Board of Directors, 9 of 12 seats should be held by representatives of Asia and Oceania. However, these restrictions are explained by the AIIB's regional focus, so they can hardly be considered as factors negatively affecting the potential participation of countries from other regions in its operations. As for the role of China, it ends up having de facto veto power in voting on the most important issues, which are decided by a super majority vote requiring three quarters of the total number of votes (China accounts for $26.1 \%$ of votes). Originally, however, the country's shares in the AIIB capital and voting power were expected to reach up to $50 \%$. Actually, these figures are now much lower and, according to Chris Humphrey, an expert on international development banks, in the future they will be further reduced and China will lose its sole dominant position in the AIIB's decision-making process [Humphrey, 2015b]. Thus, the Chinese position promotes a favorable image of the Bank and can potentially help attract additional shareholders' capital. This became apparent during discussions on the AIIB

${ }^{17}$ China to have 30 per cent stake, veto power under AIIB deal. South China Morning Post, 30 June 2015. Available at: http://www.scmp.com/news/china/diplomacy-defence/article/1829342/aiib-deal-seals-chinasbig-stake-new-lender (accessed 03 August 2016).

${ }^{18}$ Asian Infrastructure Investment Bank Articles of Agreement. Available at: http://euweb.aiib.org/uplo adfile/2016/0202/20160202043950310.pdf (accessed 03 August 2016). 
Articles of Agreement, which were open and based on the involvement of all interested states. The accession of major European economies to the AIIB demonstrates the appropriateness of the strategy chosen by China, and their representatives' participation in the Bank's governing bodies, including as vice-presidents,${ }^{19}$ shows that this strategy is still implemented.

The dominance of founding members in the NDB is more apparent and it is unclear whether it will be weakened in future. According to the Agreement on the NDB, BRICS countries share in its capital and, consequently, in the total number of votes cannot fall below 55\%. Taking into account the NDB decision-making mechanisms, this limit virtually guarantees the veto power for BRICS countries.

\section{Governance mechanisms and structure}

Significant differences determining the dominance of the founding members in the NDB are also apparent in the two banks' governance structures. According to the Articles of Agreement, the maximum number of the NDB's Board of Directors members shall be 10 , with 5 of them representing BRICS countries [BRICS Governments, 2014]. The governance system of routine NDB activities is also dominated by the BRICS countries. In fact, the daily work of the Bank is managed by the president and 4 vice-presidents representing the founding members. The president of the NDB heads "the credit and investment committee, composed also by the VicePresidents, that will be responsible for decisions on loans, guarantees, equity investments and technical assistance" [Ibid.]. This committee is designed to ensure quick decision-making in the framework of the Bank's operations, but at the same time could potentially be subject to the political influence of BRICS countries. These features of the NDB's organizational structure and policy, providing for the dominant position of BRICS countries, may adversely affect the decision on accession to the bank by new members with relatively high national incomes. In this case, NDB membership will be sought first of all by low-income countries with an acute need for financing. As a result, specific features of the Bank's governance may have a multidirectional impact on its development dynamics. On the one hand, the NDB may acquire its own niche, as-of-yet unoccupied by other multilateral development banks, financing projects mainly within the BRICS and in low-income states. On the other hand, the participation of the poorest countries may limit the potential for growth of the bank's paid-in capital, as well as diversification and reduction of risks in its loan portfolio, thus directly affecting its access to funds raised on capital markets. The mechanism for partial mitigation of this risk is incorporated in the NDB Articles of Agreement, providing for operations in countries that are not members of the Bank [BRICS Governments, 2014]. Much will depend on the NDB's sectoral priorities. Some researchers believe that diversification of the NDB operations will "foster its uniqueness and universality" [Dzhagitjan, 2015], making it attractive for new members, while the opposite point of view cites the Bank's alleged inability to accumulate expertise, develop working mechanisms and adopt advanced investment principles in case of a narrow focus on infrastructure projects [Humphrey, 2015b].

As a result, although membership in the NDB and AIIB is formally open to all states (for all UN members in the NDB, and all members of the IBRD and ADB in the AIIB), the number of founding members of the two institutions differs radically. Only the five BRICS countries are members of the NDB, whereas the AIIB membership includes 57 states representing different regions, with many of them being the world's leading economies. This situation is explained, on the one hand, by China's active position of attracting new members to the AIIB and, on the

${ }^{19}$ AIIB Vice Presidents. Asian Infrastructure Investment Bank. Available at: http://euweb.aiib.org/html/ aboutus/governance/Senior_Management/Vice_Presidents/?show=1 (accessed 03 August 2016). 
other hand, specific features of its capital structure and governance mechanisms that made the bank more attractive for potential members and contributed to its subscribed capital growth to more than USD 98 billion, compared to USD 50 billion in the NDB.

\section{Potential for raising external funds}

The most important factor that will affect the scale of operations of the two examined banks is their ability to raise funds from external sources.

Both the NDB and the AIIB have an opportunity to raise additional funds apart from payment of subscriptions by member states. Banks can borrow funds in their member countries and beyond, buy and sell securities they have issued, guaranteed or in which they have invested, place funds on deposits, and "exercise such other powers and establish such rules and regulations as may be necessary or appropriate in furtherance of its purpose and functions" [BRICS Governments, 2014].

The New Development Bank is expected to start raising funds from external sources in the near future. On 15 April 2016, the chairman of the NDB Board of Governors, Russian Finance Minister A. Siluanov, noted that the bank's management had approved the issuance of five-year bonds denominated in Chinese yuan. ${ }^{20}$ At present, borrowing in the Chinese market seems to be the only possible alternative for the NDB, given that Chinese credit rating agencies Chengxin International Credit Rating and China Lianhe Credit Rating gave their highest ratings to the bank, thus significantly reducing its cost of borrowing. ${ }^{21}$ The conditions of attracting funding in other BRICS financial markets are still unclear, although some positive steps have been made in this area. For example, on 11 March 2016, Russian Prime Minister Dmitry Medvedev signed a directive permitting the NDB and AIIB securities placement and circulation in the Russian Federation. ${ }^{22}$

However, in the future, to ensure that the cost and scope of raising capital remain acceptable, the NDB will need to obtain international credit ratings. As the Brazilian NDB Vice President Nogueira Paulo Batista informed, the bank is currently choosing between getting a credit rating of AAA or AA. ${ }^{23}$ The decline of the sovereign ratings of Brazil and Russia in 2015 negatively affected the bank's chances of obtaining the highest rating. The complex system relevant agencies use to calculate their ratings takes into account a wide range of factors, including "the methods of managing risks, capital and funding," which may become an additional barrier. ${ }^{24}$ Additionally, there are some uncertainties concerning borrowing in yuan because of the strict regulations in the Chinese financial market, as well as possible technical difficulties. As the NDB President K. Kamath mentioned, one of the main principles of the bank's strategy is financing in local currencies, which helps reduce operational costs. However, the mechanism of swapping funds received as loans in yuan into the currencies of four other BRICS countries

${ }^{20}$ BRICS bank plans 5-year bonds in Chinese yuan - Interfax. New Development Bank, 15 April 2016. Available at: http://ndb.int/brics-bank-plans-5-year-bonds-in-chinese-yuan-interfax.php (accessed 03 August 2016).

${ }^{21}$ BRICS bank hopes to receive highest rating from int'l agencies. New Development Bank, 26 February 2016. Available at: http://www.ndb.int/brics-bank-hopes-to-receive-highest-rating-from-intl-agencies.php (accessed 03 August 2016).

${ }^{22}$ Government directive of 11 March 2016 № 413-r. Available at: http://government.ru/docs/22164/ (accessed 03 August 2016).

${ }^{23}$ BRICS Bank will seek for AAA or AA credit rating // BRICS Panorama \#31 (1-7 February). National Committee on BRICS Research, 8 February 2016. Available at: http://www.nkibrics.ru/posts/ show/56b8517362726939ee080000 (accessed 03 August 2016).

${ }^{24}$ Ibid. 
is unclear. ${ }^{25}$ Also, at the moment it is difficult to assess the outcome of BRICS plans to establish its own rating agency, aimed at reducing the dependence of member economies on ratings issued by Western agencies.

As with shareholders' capital, the AIIB's prospects for attracting external financing seem to be more favorable than those of the NDB. Currently the AIIB has no credit rating, but representatives of the "big three" global rating agencies are working on its assignment. The bank's president Jin Liqun mentioned that he hopes the rating agencies will make a fair decision. At the same time, even with a credit rating below the highest possible, AIIB, as a Chinese project, will always be able to attract up to USD 20-30 billion in the Chinese market, and, as expected by Jin Liqun, this situation will ultimately have a negative impact on the reputation of the agencies. ${ }^{26}$ It is also important to note that the AIIB Articles of Agreement do not provide for rigid requirements regarding the use of national currencies in the bank's operations, thus further expanding its opportunities for borrowing. ${ }^{27}$

As noted above, the attractiveness of the examined MDBs for investors depends, inter alia, on sovereign ratings of their member countries. As of April 2015, BRICS countries had the following ratings assigned by Standard \& Poor's: Brazil $-\mathrm{BB}$, Russia $-\mathrm{BB}+$, India $-\mathrm{BBB}-$, China - AA-, South Africa - BBB-. At the same time, the largest AIIB shareholders after China, India and Russia had the following ratings: Germany - AAA, Korea - AA-, Australia - AAA, France - AA. ${ }^{28}$ Thus, the participation of leading non-regional economies in the AIIB significantly improves its potential for borrowing funds on favorable terms, which in turn should help reduce the cost of financing provided for projects and contribute to the faster growth and diversification of the bank's portfolio, compared to the NDB.

\section{Future scenarios of attracting capital and loan portfolio growth}

Once the establishment of the NDB and AIIB had been announced, less than two years passed before these institutions launched full-scale operations. Now the next stage of their activities begins, when it will be possible to assess their effectiveness in terms of their ability to achieve the main objectives, which will be primarily reflected in the growth rates of their capital and credit portfolios.

It was already clear when preparations were being made to set up the AIIB that its shareholders will include both countries from the Asia-Pacific region and developed economies from other regions of the world. Meanwhile, despite China's dominant share in the capital and its de facto veto power concerning voting on major issues, most of the key global economies have decided to participate in the Bank's activities as full members. As a result, its subscribed capital currently exceeds USD 98 billion (almost the full amount of the authorized capital). The agreed figure for the NDB subscribed capital is approximately half that, amounting to USD 50 billion.

As already mentioned, a significant part of the subscribed capital of the two banks $(80 \%$, or USD 40 billion for each bank) is callable. This type of capital is used to cover liabilities in

${ }^{25}$ Brics Development Bank Pins Hope on China Bond Sale. Joint Site of Ministries of Foreign Affairs of BRICS Member States, 14 March 2016. Available at: http://infobrics.org/blog/news/2016/03/14/11272/ (accessed 03 August 2016).

${ }^{26}$ AIIB says could rely on Chinese investors if ratings unfair. Reuters, 17 September 2015. Available at: http://www.reuters.com/article/us-aiib-china-idUSKCN0RH27E20150917 (accessed 03 August 2016).

${ }^{27}$ Asian Infrastructure Investment Bank Articles of Agreement. Available at: http://euweb.aiib.org/uplo adfile/2016/0202/20160202043950310.pdf (accessed 03 August 2016).

${ }^{28}$ Credit Rating. Trading Economics, 21 May 2016. Available at: http://www.tradingeconomics.com/ country-list/rating (accessed 03 August 2016). 
case of an emergency, but in fact does not affect the volume of ordinary operations (loans, guarantees and equity participation). Thus, paid-in capital is the main factor determining the scale of operations of the institutions examined. It amounts to more than 19.6 billion dollars for the AIIB and 10 billion - for the NDB. The growth of the banks' operations will be further limited by the approved payment schemes of subscriptions by member countries (in five installments in the $\mathrm{AIIB}^{29}$ and seven - in the NDB [BRICS Governments, 2014]). Another constraint is the limitation on ordinary operations, the total amount of which, according to the statutory documents of the two institutions ${ }^{30}$ [Ibid.], cannot exceed the sum of their subscribed capital, reserves and profits.

Data on the size of the NDB and AIIB initial capital allows predicting and comparing the growth dynamics of their loan portfolios. The forecast takes into account: the amount and payment scheme of the subscribed capital (Table 3); options for its increase in the event new members are invited or existing ones undertake additional subscriptions; the potential accumulation of reserves used to finance operations; and attracting external funding. Depending on these factors, different scenarios for the growth of the NDB and AIIB loan portfolios are possible.

Table 3. Dynamics of the NDB and AIIB paid-in capital, in accordance with the existing agreements, USD billion

\begin{tabular}{|c|c|c|}
\hline Year & NDB total paid-in capital & AIIB total paid-in capital \\
\hline 2016 & 0.75 & 3.93 \\
\hline 2017 & 2 & 7.85 \\
\hline 2018 & 3.5 & 11.78 \\
\hline 2019 & 5 & 15.70 \\
\hline 2020 & 6.5 & 19.63 \\
\hline 2021 & 8.25 & 19.63 \\
\hline 2022 & 10 & 19.63 \\
\hline
\end{tabular}

Source: Agreement on the NDB, ${ }^{31}$ Agreement on the AIIB..$^{32}$

This article explores only the basic scenario. Other scenarios may be subject to further research along with the development of the two institutions. The approach used in this article is based on the work of Chris Humphrey [Humphrey, 2015b]. However, the proposed forecast additionally takes into account new data on the activities of the two banks, leading to the adjustment of a set of parameters used for assessment and their values.

The basic forecast of the loan portfolios of the banks is developed on the basis of the following assumptions.

1. The general assumption is that borrowers will provide sufficient demand for loans from the NDB and AIIB, which will maximize the use of banks' resources for financing their operations.

${ }^{29}$ Asian Infrastructure Investment Bank Articles of Agreement. Available at: http://euweb.aiib.org/uplo adfile/2016/0202/20160202043950310.pdf (accessed 03 August 2016).

${ }^{30}$ Ibid.

${ }^{31}$ Agreement on the New Development Bank. Available at: http://www.ndb.int/download/Agreement\%20 on\%20the\%20New\%20Development\%20Bank.pdf (accessed 03 August 2016).

${ }^{32}$ Asian Infrastructure Investment Bank Articles of Agreement. Available at: http://euweb.aiib.org/uplo adfile/2016/0202/20160202043950310.pdf (accessed 03 August 2016). 
2. It is assumed that borrowers will fully repay their loans to the banks in a timely manner.

3. It is also assumed that after three years of operation, the two banks will be able to accumulate net incomes, which they can further use to finance their ordinary operations. This period will allow the banks to finish the stage where projects are planned and prepared and launch funding. This assumption also takes into account the operational documents of the NDB and AIIB, which currently don't provide for any possibility to issue loans with a grace period, typical of some MDBs.

4. Taking into account the active development of partnerships with commercial banks and other MDBs (memoranda of cooperation between the NDB and Indian ICICI, ${ }^{33}$ AIIB and the EBRD,${ }^{34}$ and AIIB and ADB,${ }^{35}$ the Co-Financing Framework Agreement between the AIIB and the World Bank $^{36}$ ), providing for co-financing of projects, it is expected that by the end of the ten-year forecast period, co-financing from governments, private investors and other MDBs will be provided in equal proportions with funding from the two examined banks.

The following assumptions are based on quantitative parameters which take into account the differences between the NDB and AIIB.

5. It is expected that the NDB will expand its membership and/or the existing members will make additional subscriptions, leading to an increase in its paid-in capital. Taking into consideration some factors that limit the attractiveness of the NDB for potential members, and the fact that discussions on the conditions of new countries' accession will only begin in $2017,{ }^{37}$ it is expected that new subscriptions will amount to USD 25 billion dollars, or a half of the authorized capital yet unsubscribed. In the event that the existing proportion between the bank's callable and paid-in capital is maintained, the latter will increase by USD 5 billion to USD 15 billion. It is supposed that payment of these subscriptions will start in 2020 in annual equal installments and last for five years (i.e. paid-in capital of the NDB will further increase by USD 1 billion annually from 2020 to 2024) [Humphrey, 2015b].

As for the AIIB, given China's active policy of attracting new members and the considerable financial resources of several founding members, the amount of additional paid-in capital is expected to reach USD 50 billion, or twice as much as the NDB figure. Similarly to the NDB, the payment of new subscriptions is expected to start in 2020 in the form of equal installments over five years.

6. The forecast for the AIIB is based on the average ratio of net income to the sum of paid-in capital and reserves (return on equity, ROE) for the leading MDBs, equal to 3.5\% (Humphrey, 2015b), and all net income is supposed to be used for replenishing reserves. For the NDB, taking into account its potential difficulties in attracting low-cost external financing

${ }^{33}$ New Development, ICICI ink 'preferred partner' pact. New Development Bank, 6 May 2016. Available at: http://ndb.int/New-Development-ICICI-ink-preferred-partner-pact.php (accessed 03 August 2016).

${ }^{34}$ Asian Infrastructure Investment Bank to cooperate with European Bank for Reconstruction and Development. Asian Infrastructure Investment Bank, 11 May 2016. Available at: http://euweb.aiib.org/ html/2016/NEWS_0511/109.html (accessed 03 August 2016).

${ }^{35}$ AIIB, ADB sign MOU to strengthen cooperation for sustainable growth. Asian Infrastructure Investment Bank, 2 May 2016. Available at: http://euweb.aiib.org/html/2016/NEWS_0502/102.html (accessed 03 August 2016).

${ }^{36}$ AIIB and World Bank sign first Co-Financing Framework Agreement. Asian Infrastructure Investment Bank, 13 April 2016. Available at: http://euweb.aiib.org/html/2016/NEWS_0414/99.html (accessed 03 August 2016).

${ }^{37}$ Anton Siluanov: BRICS Bank to determine the conditions for new members accession in 2017. Joint Site of Ministries of Foreign Affairs of BRICS Member States, 20 April 2016. Available at: http://infobrics.org/ ru/blog/news/2016/04/20/13597 (accessed 03 August 2016). 
and the need to maintain interest rates that would not "scare away" borrowers discussed above, this indicator is set equal to $3 \%$.

7. In addition, the banks' possibilities of attracting external financing are considered. The proportion between the capital of the banks and the size of their loan portfolios is characterized by the E/L (equity-to-loans) ratio. At the end of 2014 the average E/L ratio for the five key development banks (International Bank for Reconstruction and Development (IBRD) and four regional banks: the European Bank for Reconstruction and Development (EBRD), African Development Bank (AfDB), Asian Development Bank (ADB) and Inter-American Development Bank (IADB)) amounted to $37.5 \%$ (Table 4).

Table 4. E/L ratio for key development banks in 2014, \%

\begin{tabular}{|c|c|c|c|c|c|}
\hline IBRD & EBRD & AfDB & ADB & IADB & Average \\
\hline 25.3 & 54.8 & 45.9 & 29.8 & 31.8 & 37.5 \\
\hline
\end{tabular}

Source: African Development Bank..$^{38}$

This forecast for the AIIB is based on the average $\mathrm{E} / \mathrm{L}$ ratio $(37.5 \%)$, whereas for the NDB, taking into account the comparably less favorable terms of its access to external financing, the figure is 5 p.p. higher $(42.5 \%)$.

Based on these assumptions, the banks' total shareholder equity is calculated, consisting of shareholders' contributions made according to the set schedules and reserves. Then, capital and loan portfolio growth forecasts for the NDB and AIIB are made. Taking into consideration the data on the total shareholder equity level and expected $\mathrm{E} / \mathrm{L}$ ratio, the AIIB loan portfolio is forecasted to expand to USD 96 billion by 2025 if all the assumptions specified above are true.

The NDB in the same period is expected to build up a loan portfolio of up to USD 41 billion. The predicted dynamics of the NDB and AIIB loan portfolios are presented below (Fig. 1).

Given the differences between the banks in capital structure, governance mechanisms and policies for attracting new members, the AIIB credit portfolio after 10 years of activity may be more than twice as big as that of the NDB. In total, taking into account co-financing and setting the loan period equal to $7-8$ years, the new banks will be able to provide investment in infrastructure worth up to USD 40 billion annually by 2025 .

The presented analysis shows that over a period of ten years, the scale of the AIIB operations can grow quite rapidly, allowing the bank to accumulate a loan portfolio, comparable to or even exceeding that of the key regional development banks [Humphrey, 2015b] (for example, as of end 2015, the loan and grant portfolio of the ADB slightly exceeded USD 73 billion) [Asian Development Bank, 2016]. This growth can be positively affected both by a large number of member countries providing subscriptions to the bank's capital and the fact that many of them, especially non-regional members, are advanced economies with high sovereign ratings and thus may contribute to the bank having higher credit ratings itself. The dominant position of China is also an advantage for the AIIB, allowing it to raise funds in the liquid Chinese capital market more actively, and helping create a positive image of the bank among investors. The growth of the NDB operations will not be so swift, because relevant positive factors are not so apparent. However, there are some, including clear differences from the "traditional" MDBs established in the framework of the Bretton Woods system, which lead to greater equality among

${ }^{38}$ African Development Bank. Available at: http://www.afdb.org/fileadmin/uploads/afdb/Documents/ Financial-Information/Moodys_Rating_2015.pdf (accessed 03 August 2016). 
participants, as well as the bank's potential for finding its own niche in financing infrastructure projects [Schablitzki, 2014].

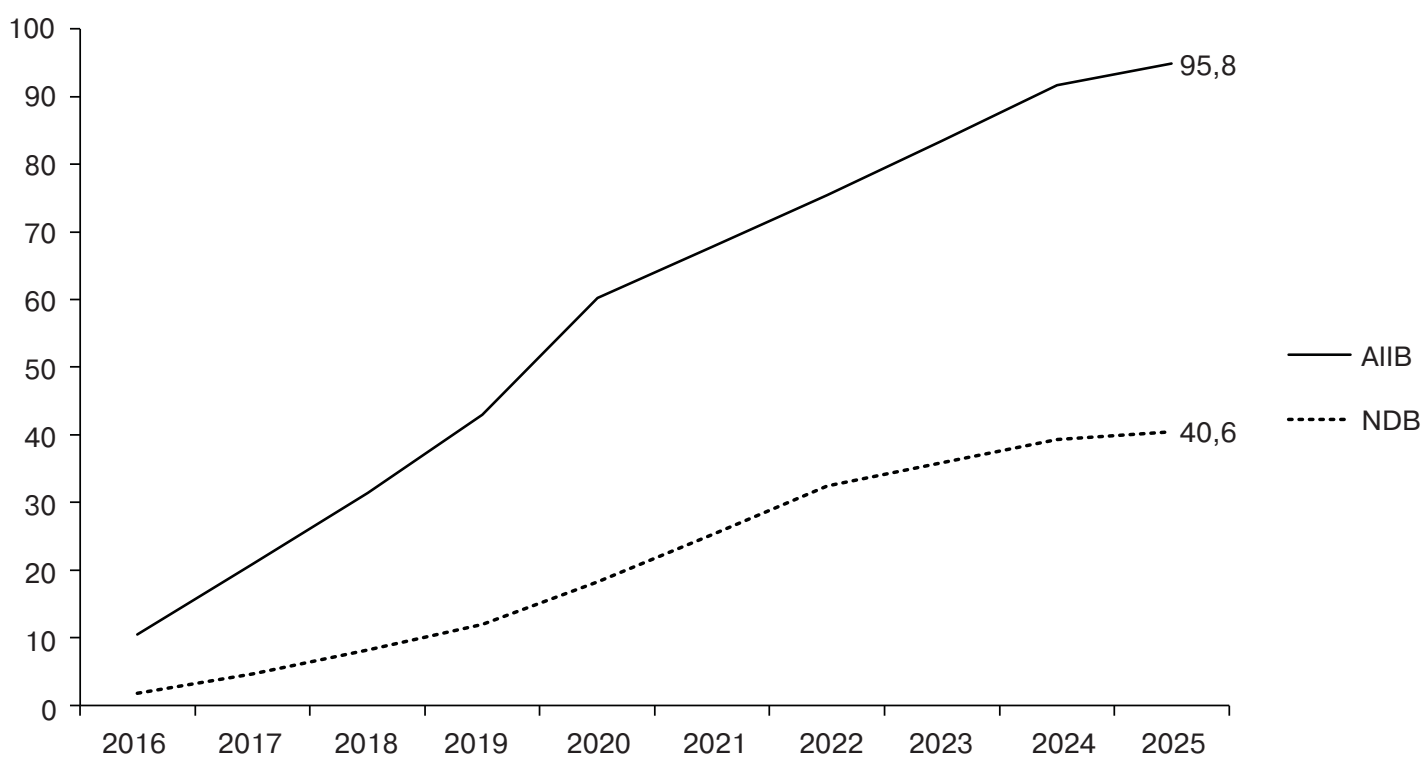

Fig. 1. Forecast for NDB and AIIB loan portfolios' growth, USD bln

Source: author's estimations.

As a result, the advantages of the AIIB governance strategy and policies are expected to contribute to its loan portfolio growing more rapidly than that of the NDB. At the same time, the development scenarios of the banks may change significantly due to the potentially negative impact of several factors. For the AIIB these include duplication of its geographical and sectoral priorities by another major specialized institution - the Asian Development Bank, and bank's dependence on the political will of China and the state of its economy [Humphrey et al., 2015]. Potential negative factors for the NDB are dominance of the BRICS countries in its governance, reducing the incentives for new members to accede, as well cautious attitudes among investors.

\section{Conclusion}

The establishment of the NDB and AIIB was a response to the growing demand for infrastructure financing in developing countries, the leading emerging economies' aspirations for a greater role in international financial institutions and the need for the efficient use of reserves accumulated in these countries.

If their development is successful, the two new institutions can channel resources of developing countries and emerging economies to address development needs, especially in infrastructure; facilitate integration of these countries into the global governance system on acceptable terms; fit current economic and political realities to a greater extent as compared to "traditional" MDBs; and provide incentives for the full implementation of urgent, but permanently delayed governance reforms of other international institutions.

At the same time, just as the new MDBs are being established, differences have emerged in their basic parameters and policies that in the future could significantly affect the speed and 
scale of their development. The analysis of these factors shows that conditions for increasing the loan portfolio - the main indicator of MDBs' operations - are more favorable for the AIIB than for the NDB.

However, based on the proposed forecast, one can hardly conclude that to establish the NDB and AIIB as "strong and respected international financial institutions, playing a leading role in the evolving international financial architecture" [Griffith-Jones, 2014] their founding members will need to make different efforts. Scaling up operations will be a challenge for both banks, as evidenced by the long history of "traditional" MDBs, for several reasons. These include the lack of relevant experience and need to accumulate best practices, which will take some time; potential difficulties in ensuring the adequate skills of staff and maintaining the quality of expert and technical assistance; the need to create a positive image to raise external funding; difficulties in establishing monitoring mechanisms related to environmental and social protection and financial supervision; the trade-off between finding their own operational niche and potential fragmentation of the development financing system through MDBs [Humphrey et al., 2015].

Given several common risks that the NDB and AIIB face, the banks need to actively engage with each other and cooperate with other MDBs in order to strengthen their positions in the global financial architecture. According to the forecast presented in this article, the total loan portfolio of the two banks could exceed USD 135 billion in 10 years. Taking into account the average loan term of 7 to 8 years and potential co-financing of projects by governments and private investors in equal proportions with the banks, their annual additional funding could be around USD 40 billion. Being relatively small at first glance, these investments will nevertheless make up a significant contribution to the elimination of infrastructure financing deficit, comparable with that of other MDBs, whose total portfolio of projects in all sectors in developing countries and emerging economies stands at about USD 700 billion. ${ }^{39}$ The first steps have already been made to promote such cooperation. Representatives of the NDB constantly declare their willingness to engage with the AIIB in projects in the Asian region based on the complementarity of the purposes of the two banks, ${ }^{40}$ and AIIB has signed the Co-Financing Framework Agreement with the World Bank ${ }^{41}$ and memoranda on cooperation with the ADB ${ }^{42}$ and EBRD. ${ }^{43}$

Thus, in a short period of time, new development banks have managed to launch their operations, which in the near future will make a meaningful contribution to the elimination of the infrastructure financing gap. The differences in scope and pace of growth of their attracted resources and loan portfolios are explained primarily by the composition of membership and differences in members' views regarding the future development of the two institutions, which

${ }^{39}$ The Asian Infrastructure Investment Bank. A New Multilateral Financial Institution or a Vehicle for China’s Geostrategic Goals. European Political Strategy Center Strategic Note, Issue 1, 24 April 2015. Available at: http://ec.europa.eu/epsc/publications/notes/sn1_en.htm (accessed 03 August 2016).

${ }^{40}$ New Development Bank not a rival institution but complementary to AIIB. New Development Bank, 28 March 2016. Available at: http://ndb.int/new-development-bank-not-a-rival-institution-but-complementary-to-aiib.php (accessed 03 August 2016).

${ }^{41}$ World Bank and AIIB Sign First Co-Financing Framework Agreement. World Bank, 13 April 2016. Available at: http://www.worldbank.org/en/news/press-release/2016/04/13/world-bank-and-aiib-sign-firstco-financing-framework-agreement (accessed 03 August 2016).

${ }^{42}$ AIIB, ADB sign MOU to strengthen cooperation for sustainable growth. Asian Infrastructure Investment Bank, 2 May 2016. Available at: http://euweb.aiib.org/html/2016/NEWS_0502/102.html (accessed 03 August 2016).

${ }^{43}$ Asian Infrastructure Investment Bank to cooperate with European Bank for Reconstruction and Development. Asian Infrastructure Investment Bank, 11 May 2016. Available at: http://euweb.aiib.org/ html/2016/NEWS_0511/109.html (accessed 03 August 2016). 
in turn largely determines all the rest of the parameters examined. In this regard, Russia, as one of the NDB's founding members and one of the AIIB's largest shareholders, should make greater use of the expertise and financial capacities of the two banks in order to address national economic development challenges and strengthen its role in the international financial system. In the near future, the NDB and AIIB will become effective instruments of infrastructure development, and "Russia will have to learn how to use them to augment its own long-term economic benefits" [Ivanter, 2015].

\section{References}

Asian Development Bank (2016) Quarterly Portfolio Update as of 31 December 2015. Available at: http://www. adb.org/sites/default/files/institutional-document/181407/in60-16.pdf (accessed 3 August 2016).

Bhattacharya A., Romani M. (2013) Meeting the Infrastructure Challenge: The Case for a New Development Bank. Presentation prepared for the G-24 Technical Group Meeting, 21 March. Available at: http://g24.org/ wp-content/uploads/2014/03/Session-4_2.pdf (accessed 3 August 2016).

BRICS Governments (2014) Agreement on the New Development Bank. Available at: http://www.ndb.int/ download/Agreement\%20on\%20the\%20New\%20Development\%20Bank.pdf (accessed 3 August 2016).

BRICS Leaders (2012) Delhi Declaration, 29 March. Available at: http://www.nkibrics.ru/pages/summit-docs (accessed 3 August 2016).

BRICS Leaders (2013) Ethekwini Declaraton and Ethekwini Action Plan, 27 March. Available at: http://www. nkibrics.ru/pages/summit-docs (accessed 3 August 2016).

BRICS Leaders (2013) Media Note on the Informal Meeting of BRICS Leaders Ahead of the G20 Summit in St. Petersburg. Available at: http://brics.utoronto.ca/docs/130905-note.html (accessed 3 August 2016).

BRICS Leaders (2014) Fortaleza Declaration, 15 June. Available at: http://www.nkibrics.ru/pages/summitdocs (accessed 3 August 2016).

BRICS Leaders (2015) Ufa Declaration, 9 July. Available at: http://www.nkibrics.ru/pages/summit-docs (accessed 3 August 2016).

Dzhagitjan J.P. (2015) Institucionalizacija jekonomicheskogo mehanizma gruppy BRIKS: preimushhestva i riski Novogo banka razvitija (Instutionalization of BRICS economic mechanism: advantages and risks of the New Development Bank). Den'gi i kredit, no 6. Available at: http://www.cbr.ru/publ/moneyandcredit/ djagityan_06_15.pdf (accessed 3 August 2016). (In Russian.)

Griffith-Jones S. (2011) South-South Financial Cooperation. Background Paper, no 2 to UNCTAD's Least Developed Countries Report. Available at: http://www.stephanygj.net/papers/southsouthfinancial cooperation2012.pdf (accessed 3 August 2016).

Griffith-Jones S. (2014) A BRICS Development Bank: A Dream Coming True? UNCTAD Discussion Paper, no 215. Available at: http://unctad.org/en/PublicationsLibrary/osgdp20141_en.pdf (accessed 3 August 2016).

Griffith-Jones S. (2015) Financing Global Development: The BRICS New Development Bank. German Development Institute Briefing Paper 13/2015. Available at: https://www.die-gdi.de/uploads/media/ BP_13.2015.pdf (accessed 3 August 2016).

Humphrey C. (2015a) Challenges and Opportunities for Multilateral Development Banks in 21st Century Infrastructure Finance. The Global Green Growth Institute and the Intergovernmental Group of Twenty Four on Monetary Affairs and Development (G-24). Available at: https://www.academia.edu/14934974/ Challenges_and_Opportunities_for_Multilateral_Development_Banks_in_21st_Century_Infrastructure_ Finance?auto $=$ download (accessed 3 August 2016).

Humphrey C. (2015b) Developmental Revolution or Bretton Woods Revisited? The prospects of the BRICS New Development Bank and the Asian Infrastructure Investment Bank. ODI Working Paper 418. Available at: https://www.odi.org/sites/odi.org.uk/files/odi-assets/publications-opinion-files/9615.pdf (accessed 3 August 2016). 
Humphrey C. et al. (2015) Multilateral Development Banks in the 21 ${ }^{\text {st }}$ Century. Three Perspectives on China and the Asian Infrastructure Investment Bank. ODI Discussion Paper. Available at: https://www.odi.org/sites/odi. org.uk/files/odi-assets/publications-opinion-files/10097.pdf (accessed 3 August 2016).

Ivanter A. (2015) Koncert nacij, a ne kitajskij orkestr (Concert of nations rather than a Chinese orchestra). Expert, no 26-27. Available at: http://www.veb.ru/common/upload/files/veb/inter/20150629_1.pdf (accessed 3 August 2016) (in Russian).

Schablitzki J. (2014) The BRICS Development Bank: A New Tool for South-South Cooperation? BPC Policy Brief, vol. 5, no 1. Available at: http://bricspolicycenter.org/homolog/uploads/trabalhos/6766/doc/168701850. pdf (accessed 3 August 2016). 